\title{
Assessing the Toxic Potential of Insecticide and Indigenous Botanical Extract against the Stored Grain Pest Tribolium castaneum (Coleoptera: Tenebrionidae)
}

\author{
Batool Zuhra ${ }^{1}$, Khalil Ahmad ${ }^{1}$, Shaukat Ali ${ }^{2 *}$, Azhar Hussain ${ }^{3}$, Maisoor Ahmad Nafees ${ }^{1}$, \\ Salar Ali ${ }^{4}$, Muhammad Ali ${ }^{1}$, Sadiq Hussain ${ }^{5}$, Zulfiqar Ali $^{3}$ \\ ${ }^{1}$ Department of Biological Sciences, Karakoram International University, Gilgit-Baltistan, Pakistan \\ ${ }^{2}$ Department of Environmental Sciences, Karakoram International University, Gilgit-Baltistan, Pakistan \\ ${ }^{3}$ Department of Food and Agriculture Technology, Karakoram International University Gilgit-Baltistan, Pakistan \\ ${ }^{4}$ Laboratory of Watershed Geographic Sciences, Institute of Geography and Limnology, \\ Chinese Academy of Sciences, Nanjing, China \\ ${ }^{5}$ Department of Behavioral Sciences, Karakoram International University, Gilgit-Baltistan, Pakistan
}

Received: 15 June 2017

Accepted: 29 October 2017

\begin{abstract}
The current investigation was undertaken to assess the toxic potential of synthetic insecticides (K.Othrin and bio-max) and botanical extracts (Mentha royleana L. and Artemisia absinthium L.) against Tribolium castaneum in the laboratory. Different concentrations of insecticides and botanical extracts were used following complete randomized block design. The results indicated that the toxic effects were directly proportional to concentrations of insecticide and botanical extracts. Higher concentrations had more resilient toxicity than lower concentrations. Among the tested insecticides, Biomax (Chlorpyrifos) showed $>90 \%$ and K-Othrin (Deltamethrin) $<80 \%$ mean toxic effect at $2 \%$ concentrations. In the botanical extract, Mentha royleana toxicity at $5 \%$ concentration is $>90 \%$ as compared to Artemisia absinthium against $T$. Castaneum. The results could be helpful in designing an effective management plan for the control of T. castaneum.
\end{abstract}

Keywords: insecticides, botanical extract, toxicity, wheat flour pest, Tribolium castaneum

\section{Introduction}

The red flour beetle T. castaneum (Herbst) (Coleoptera: Terebrionidae) is a cosmopolitan species and causes considerable loss to stored food grains [1]. Managing storage food grain pests is not a current issue. Various recommendations of grain storage techniques using different natural products to kill or keep away the infesting insect pests have been advised by previous researchers [2-3]. T. castaneum is a common and most destructive pest throughout the world and is generally

*e-mail: dr.shaukat@kiu.edu.pk 
found in granaries, mills, and warehouses [4]. It causes serious damages to all kinds of stored grain products [5]. Many plant preparations are studied for insecticidal actions [6-8], and these preparations showed positive actions against pests. The plant-derivative chemical activates after plant extract screening and has been used as an active protectant and antifeedant, and insecticides and natural antifeedants are used to control pests, to avoid environmental pollution, and to reduce the use of synthetic pesticides [9-10]. The use of plant pesticides is low cost, suitable to use, and environmentally friendly.

About $35 \%$ of world crops are damaged by different insects [11]. In Pakistan pest insects have been documented nourishing on grains and its foodstuffs. Most of the destruction is done by the granary weevil, lesser grain borer, rice weevil, khapra beetle, rice moth, and flour beetle, and not only damages grains but also reduces nutritional value [12]. So, worldwide environmentalists are declaring less use of tenacious insecticides.

The harmful effect of plant extracts and pure compounds on insects can be demonstrated in numerous ways, including antifeedant, growth inhibitor, toxicity, suppression of reproductive behavior, mortality, and reduction of fertility and fecundity [13-15].

Red flour beetle (Herbst) is a global insect pests of mills, food warehouses, retail stores, and urban homes [7, 16]. Therefore, this study is based on the toxicological effects of indigenous floras of Gilgit against $T$. castaneum, as there is no proper storage in Gilgit to protect food materials from insect infestation. This study will be helpful for managing the storage of flour from red flour beetle ( $T$. castaneum) infestation in storage bins and control the flour beetle by using local plant extracts with comparison to chemical pesticides.

\section{Materials and Methods}

\section{Insect Collection and Rearing}

Insect $T$. castaneum was collected from naturally infected flour bins and reared in glass jars in the Research Laboratory Department of Biological Science, Karakoram International University under controlled conditions. During the nurturing period the temperature $\left(25 \pm 1^{\circ} \mathrm{C}\right)$, relative humidity $(60 \pm 5 \%)$, and food were provided to the test organisms. Ten-day-old adults were used for all trials.

\section{Test Materials}

The insecticides K. Othrin and Bio-max and botanical extracts Mentha royleana L. and Artemisia absinthium $\mathrm{L}$. at concentration were tested against $\mathrm{T}$. castaneum.

\section{Plant Material and Insecticide Assay}

Fresh leaves of the plants Mentha royleana L. and Artemisia absinthium L. were collected during 2014-2015 from different areas of District Gilgit. The collected plants were washed with water, dried in shade, and ground to a fine powder. The plant extracts were prepared following the method described by Valsaraj et al. [17]. One-hundred grams of powder was mixed separately in $300 \mathrm{~mL}$ of ethanol $99 \%(\mathrm{w} / \mathrm{v})$ ratio at room temperature. The mixtures were stirred for 45 minutes in an ultrasonic bath at constant temperature of $25^{\circ} \mathrm{C}$, left to stand for 72 hours, and shacked several times at certain intervals. Finally, different concentrations including $5,2.5,1.25,0.63$, and $0.31 \%$ of each extract were made. In order to test the insecticide toxicity against $T$. castaneum we studied two insecticides, K. Othrin and bio-max, at five concentrations: $2,1,0.5$, 0.25 . and $0.13 \%$.

\section{Toxicity of Plant Extract and Synthetic Insecticide}

Plant extracts and synthetic insecticide were tested by filter paper impregnation method. The filter was dipped in different concentrations of plant extract and synthetic insecticide as described earlier. The wetted filter papers were placed in sterilized Petridis and inoculated 10 adult insect of $T$. castaneum against each concentration and maintained 3 replicates along with control. All the data obtained were subjected to one-way analysis of variance at $5 \%$ significance level, and means were separated using Duncan's multiple range tests. Mortality was calculated by the following formula:

$$
\mathrm{MP}=\frac{\mathrm{IC}-\mathrm{IT}}{\mathrm{IC}} \times 100
$$

MP = Mortality percentage; IC = Insect in control; IT = Insect in treatment

\section{Results and Discussion}

T. castaneum was exposed for 5 days to 2 indigenous plant extracts and two synthetic insecticides at different concentrations. The results depict dose rate having significant effects on the mortality of the tested insects.

\section{Insecticide Biomax (Chlorpyrifos)}

Different concentration of Biomax were used to assess toxicity and mortality against the flour beetle (T. castaneum). The selected concentrations for Biomax were $2 \%, 1 \%, 0.5 \%, 0.25 \%$, and $0.125 \%$. Mortality rate increased with higher concentrations of the tested chemical. The observed mortalities at concentrations of $2 \%$ were $100 \%, 100 \%, 90 \%, 80 \%$, and $90 \%$ on days $1-5$, respectively. For $1 \%$ concentrations, the observed mortalities were $100 \%, 90 \%, 80 \%, 60 \%$, and $80 \%$. 
Table 1 . Toxicity test of $\mathrm{K}$. Othrin against $T$. Castaneum at different concentrations/hour.

\begin{tabular}{|c|c|c|c|c|c|}
\hline Conc. \% & $1^{\text {st }}$ day & $2^{\text {nd }}$ day & $3^{\text {rd day }}$ & $4^{\text {th }}$ day & $5^{\text {th }}$ day \\
\hline $2 \%$ & $\begin{array}{c}7.0^{\mathrm{a}} \\
(70 \%)\end{array}$ & $\begin{array}{c}8.0^{\mathrm{a}} \\
(80 \%)\end{array}$ & $\begin{array}{c}7.0^{\mathrm{a}} \\
(70 \%)\end{array}$ & $\begin{array}{c}7.0^{\mathrm{a}} \\
(70 \%)\end{array}$ & $\begin{array}{c}8.0^{\mathrm{a}} \\
(80 \%)\end{array}$ \\
\hline $1 \%$ & $\begin{array}{c}6.0^{\mathrm{a}} \\
(60 \%)\end{array}$ & $\begin{array}{c}6.0^{\mathrm{ab}} \\
(60 \%)\end{array}$ & $\begin{array}{c}7.0^{\mathrm{a}} \\
(70 \%)\end{array}$ & $\begin{array}{c}7.0^{\mathrm{a}} \\
(70 \%)\end{array}$ & $\begin{array}{c}6.0^{\mathrm{ab}} \\
(60 \%)\end{array}$ \\
\hline $0.50 \%$ & $\begin{array}{c}2.0^{\mathrm{b}} \\
(20 \%)\end{array}$ & $\begin{array}{c}4.0^{\mathrm{bc}} \\
(40 \%)\end{array}$ & $\begin{array}{c}6.0 \mathrm{a} \\
(60 \%)\end{array}$ & $\begin{array}{l}4.0 \mathrm{ab} \\
(40 \%)\end{array}$ & $\begin{array}{c}4.0 \mathrm{~b} \\
(40 \%)\end{array}$ \\
\hline $0.25 \%$ & $\begin{array}{c}2.0^{\mathrm{b}} \\
(20 \%)\end{array}$ & $\begin{array}{c}4.0^{\mathrm{bc}} \\
(40 \%)\end{array}$ & $\begin{array}{c}4.0^{\mathrm{ab}} \\
(40 \%)\end{array}$ & $\begin{array}{c}2.0^{\mathrm{b}} \\
(20 \%)\end{array}$ & $\begin{array}{c}3.0^{\mathrm{b}} \\
(30 \%)\end{array}$ \\
\hline $0.12 \%$ & $\begin{array}{c}1.0^{\mathrm{b}} \\
(10 \%)\end{array}$ & $\begin{array}{c}2.0^{c} \\
(20 \%)\end{array}$ & $\begin{array}{c}1.0^{\mathrm{b}} \\
(10 \%)\end{array}$ & $\begin{array}{c}1.0^{\mathrm{b}} \\
(10 \%)\end{array}$ & $\begin{array}{c}3.0^{\mathrm{b}} \\
(30 \%)\end{array}$ \\
\hline $\begin{array}{l}\text { STD. Err. } \\
\text { LSD } \\
\text { LC }_{50}\end{array}$ & $\begin{array}{c}1.461 \\
3.254 \\
1.38\end{array}$ & $\begin{array}{c}1.633 \\
3.639 \\
1.58\end{array}$ & $\begin{array}{c}1.461 \\
3.254 \\
1.36\end{array}$ & $\begin{array}{c}1.461 \\
3.254 \\
1.19\end{array}$ & $\begin{array}{c}1.633 \\
3.639 \\
1.54\end{array}$ \\
\hline
\end{tabular}

Means in each row followed by the same letter are not significantly different at LSD test $(\mathrm{P}=0.05)$, while numbers in parenthesis indicate inhibition percentage over control

For $0.5 \%$ concentrations, the observed mortalities were $50 \%, 40 \%, 40 \%, 50 \%$, and $40 \%$. For $0.25 \%$ concentrations, the observed mortalities were $20 \%$, $30 \%, 30 \%, 40 \%$, and $30 \%$. For $0.125 \%$ concentrations, the observed mortalities were $20 \%, 10 \%, 10 \%, 20 \%$, and $10 \%$ on days $1-5$, respectively (Table 1 ).

\section{Insecticide K-othrin (Deltamethrin)}

The mean in each row followed by the same letter are not significantly different at LSD test $(\mathrm{P}=0.05)$, while numbers in parenthesis indicate inhibition percentage over control. Different concentrations of K-Othrin were used to evaluate toxicity and mortality against the flour beetle (T. castaneum). The data presented in Table 2 revealed that the higher the concentration of pesticides, the maximum mortality of test insects were observed.
The particular concentrations of K-othrin were $2 \%, 1 \%$, $0.5 \%, 0.25 \%$, and $0.125 \%$ for assessment. Maximum mortalities were $80 \%$ (days 2 and 5 ) and $70 \%$ (days 1 , $3-4)$ showed at the concentration of $2 \%$. Meanwhile, the decrease of the concentration to $0.125 \%$ mortality was only $10 \%$ on days 1,3 , and 4 , and on day 5 the observed mortality was $30 \%$ (Table 2 ).

\section{Plant Extract Mentha royleana}

Five different concentrations of Mentha royleana were selected for the estimating toxicity and mortality against $T$. castaneum. The results revealed that concentration and mortality were directly proportional. At $5 \%$ concentration of extract of Mentha royleana the mortalities were $100 \%, 100 \%, 100 \%, 100 \%$, and $70 \%$. At $2.50 \%$ concentration of extract the mortalities

Table 2. Toxicity test of Bio-max against $T$. Castaneum at different concentrations/hour.

\begin{tabular}{|c|c|c|c|c|c|}
\hline Conc. \% & $1^{\text {st }}$ day & $2^{\text {nd }}$ day & $3^{\text {rd }}$ day & $4^{\text {th }}$ day & $5^{\text {th }}$ day \\
\hline $2 \%$ & $\begin{array}{c}10.0^{\mathrm{a}} \\
(100 \%)\end{array}$ & $\begin{array}{c}10.0^{\mathrm{a}} \\
(100 \%)\end{array}$ & $\begin{array}{c}9.0^{\mathrm{ab}} \\
(90 \%)\end{array}$ & $\begin{array}{c}8.0^{\mathrm{b}} \\
(80 \%)\end{array}$ & $\begin{array}{c}9.0^{\mathrm{ab}} \\
(90 \%)\end{array}$ \\
\hline $1 \%$ & $\begin{array}{c}10.0^{\mathrm{a}} \\
(90 \%)\end{array}$ & $\begin{array}{c}9.0^{\mathrm{a}} \\
(90 \%)\end{array}$ & $\begin{array}{c}8.0^{\mathrm{b}} \\
(80 \%)\end{array}$ & $\begin{array}{c}6.0^{c} \\
(60 \%)\end{array}$ & $\begin{array}{c}8.0^{\mathrm{b}} \\
(80 \%)\end{array}$ \\
\hline $0.50 \%$ & $\begin{array}{c}5.0^{\mathrm{b}} \\
(50 \%)\end{array}$ & $\begin{array}{c}5.0^{\mathrm{b}} \\
(50 \%)\end{array}$ & $\begin{array}{c}4.0^{\mathrm{c}} \\
(40 \%)\end{array}$ & $\begin{array}{c}5.0^{\text {cd }} \\
(50 \%)\end{array}$ & $\begin{array}{c}4.0^{\mathrm{c}} \\
(40 \%)\end{array}$ \\
\hline $0.25 \%$ & $\begin{array}{c}2.0^{\mathrm{c}} \\
(20 \%)\end{array}$ & $\begin{array}{c}3.0^{c} \\
(30 \%)\end{array}$ & $\begin{array}{c}3.0^{\mathrm{c}} \\
(30 \%)\end{array}$ & $\begin{array}{c}4.0^{\mathrm{d}} \\
(40 \%)\end{array}$ & $\begin{array}{c}3.0^{\mathrm{c}} \\
(30 \%)\end{array}$ \\
\hline $0.12 \%$ & $\begin{array}{c}2.0^{\mathrm{c}} \\
(20 \%) \\
\end{array}$ & $\begin{array}{c}2.0^{\mathrm{c}} \\
(20 \%) \\
\end{array}$ & $\begin{array}{c}1.0^{\mathrm{d}} \\
(10 \%)\end{array}$ & $\begin{array}{c}2.0^{\mathrm{e}} \\
(20 \%) \\
\end{array}$ & $\begin{array}{c}1.0^{\mathrm{d}} \\
(10 \%)\end{array}$ \\
\hline STD. Err. & 1.08 & 0.88 & 0.68 & 0.68 & 0.68 \\
\hline $\begin{array}{l}\mathrm{LSD} \\
\mathrm{LC}_{50}\end{array}$ & $\begin{array}{l}.41 \\
0.92 \\
\end{array}$ & $\begin{array}{l}1.96 \\
0.98 \\
\end{array}$ & $\begin{array}{l}1.52 \\
1.03 \\
\end{array}$ & $\begin{array}{l}1.52 \\
1.58 \\
\end{array}$ & $\begin{array}{l}1.52 \\
1.03 \\
\end{array}$ \\
\hline
\end{tabular}

Means in each row followed by the same letter are not significantly different at LSD test $(\mathrm{P}=0.05)$, while numbers in parenthesis indicate inhibition percentage over control 
Table 3. Toxicity test of Mentha royleana against T. Castaneum at different concentrations/hour.

\begin{tabular}{|c|c|c|c|c|c|}
\hline Conc. \% & $1^{\text {st }}$ day & $2^{\text {nd }}$ day & $3^{\text {rd }}$ day & $4^{\text {th }}$ day & $5^{\text {th }}$ day \\
\hline \multirow[t]{2}{*}{$5 \%$} & $7.0^{\mathrm{a}}$ & $10.0^{\mathrm{a}}$ & $10.0^{\mathrm{a}}$ & $10.0^{\mathrm{a}}$ & $10.0^{\mathrm{a}}$ \\
\hline & $(70 \%)$ & $(100 \%)$ & $(100 \%)$ & $(100 \%)$ & $(100 \%)$ \\
\hline \multirow[t]{2}{*}{$2.50 \%$} & $6.0^{\mathrm{a}}$ & $9.0^{\mathrm{a}}$ & $8.0^{\mathrm{ab}}$ & $8.0^{\mathrm{ab}}$ & $9.0^{\mathrm{a}}$ \\
\hline & $(60 \%)$ & $(90 \%)$ & $(80 \%)$ & $(80 \%)$ & $(90 \%)$ \\
\hline \multirow[t]{2}{*}{$1.25 \%$} & $6.0^{\mathrm{a}}$ & $8.0^{\mathrm{a}}$ & $8.0^{\mathrm{ab}}$ & $8.0^{\mathrm{ab}}$ & $7.0^{\mathrm{ab}}$ \\
\hline & $(60 \%)$ & $80 \%$ & $(80 \%)$ & $(80 \%)$ & $(70 \%)$ \\
\hline \multirow[t]{2}{*}{$0.63 \%$} & $2.0^{\mathrm{b}}$ & $4.0^{\mathrm{b}}$ & $5.0^{\mathrm{bc}}$ & $6.0^{\mathrm{bc}}$ & $5.0^{\mathrm{bc}}$ \\
\hline & $(20 \%)$ & $(40 \%)$ & $(50 \%)$ & $(60 \%)$ & $(50 \%)$ \\
\hline \multirow[t]{2}{*}{$0.31 \%$} & $1.0^{\mathrm{b}}$ & $2.0^{\mathrm{b}}$ & $2.0^{\mathrm{c}}$ & $3.0^{\mathrm{c}}$ & $3.0^{\mathrm{c}}$ \\
\hline & $(10 \%)$ & $(20 \%)$ & $(20 \%)$ & $(30 \%)$ & $(30 \%)$ \\
\hline STD. Err. & 1.461 & 1.633 & 1.633 & 1.633 & 1.633 \\
\hline $\begin{array}{l}\text { LSD } \\
\text { LC }_{50}\end{array}$ & $\begin{array}{c}3.254 \\
3.18\end{array}$ & $\begin{array}{c}3.639 \\
2.28\end{array}$ & $\begin{array}{c}3.639 \\
2.51\end{array}$ & $\begin{array}{c}3.639 \\
2.99\end{array}$ & $\begin{array}{c}3.639 \\
2.94\end{array}$ \\
\hline
\end{tabular}

Means in each row followed by the same letter are not significantly different at LSD test $(\mathrm{P}=0.05)$, while numbers in parenthesis indicate inhibition percentage over control

were $90 \%, 80 \%, 80 \%, 90 \%$, and $60 \%$. And for $1.25 \%$ concentration the mortalities were $70 \%, 80 \%, 80 \%$, $80 \%$, and $60 \%$. For $0.63 \%$ concentration of extract of Mentha royleana the mortalities were $50 \%, 60 \%, 50 \%$, $40 \%$, and $20 \%$. At concentrations of $0.31 \%$ extract of Mentha royleana, the mortalities were $30 \%, 30 \%, 20 \%$, $20 \%$, and $10 \%$ on days $5,4,3,2$, and 1 , respectively, for all five concentrations (Table 3 ).

\section{Plant Extract Artemisia absinthium}

Different concentrations of Artemisia absinthium were used to assess toxicity and mortality against the flour beetle ( $T$. castaneum). The selected concentrations for the treatment were $5 \%, 2.5 \%, 1.25 \%, 0.63 \%$, and $0.3125 \%$. Highest mortality was shown by the extract with higher concentration, and while the concentration decreased mortality also decreased. At 5\% concentration the highest mortalities detected were $90 \%$ (day 3), $80 \%$ (day 4), 70\% (days 1-2) and 60\% (day 5). For $2.5 \%$ concentration of extract the mortalities were $70 \%$ (days 3-4), $60 \%$ (days 2 and 5), and 50\% (day 1). For $1.50 \%$ concentration the mortalities detected were 50\% (days $2-3$ ), $40 \%$ (day 5), and $30 \%$ and $20 \%$ on days 4 and 1 , respectively. Likewise, at $0.625 \%$ of the extract concentration the mortality was reduced and recorded data were $40 \%$ (day 2), 30\% (days 3-5), and 20\% (day 1). Similar results were observed for the $0.3125 \%$ concentration, which means the lowest mortality was observed at the lowest concentration (Table 4).

As compared to synthetic pesticides, natural products are preferred for use against pest infestation due to less mammalian toxicity. The purpose of our studies was to use indigenous plants having potential to cause mortality of the storage grain pests. For preparation of extracts of Mentha royleana and Artemisia absinthium, methanol was used as a solvent while water as a solvent was used for preparing different concentrations of pesticides (Biomax and K-Othrin). Five different concentrations of $M$. royleana and $A$. absinthium extract were studied for toxicity against $T$. Castaneum. Both the pesticides and plants extracts showed a toxic effect. At higher concentration, the mortality rate of $T$. Castaneum was increased, which means that the mortality and concentrations were directly proportional and at the lowest concentration the mortality rate also decreased. The results of the current study are in consonance with the results of other scientists. They used different plant extracts with different concentrations, but the relationships between concentration and mortality were the same. In the present study, pyrethrin, a contact poison from the pyrethroid group, was used to evaluate the toxic effect against $T$. Castaneum. The effect was maximum at the higher concentration against $T$. Castaneum, but was reduced by lowering its concentration (Tables 1-2). Similar work has been reported by Toews et al. [18], and mortality was more than $80 \%$ on all progressive stages of $T$. castaneum exposed to pyrethrin aerosol. Arthur [19] also reported the efficacy of pyrethrin aerosol to control Tribolium confusum in food storage facilities. Islam and Talukder [20] evaluated the residual and direct toxicities of commercial insecticides carbaryl and Malathion along with leaf powder and seed extracts of Cynodon dactylon (durba), Azadirachta indica (neem), and Tagetes erecta (marigold), which were tested against T. castaneum (red flour beetle). Their results concluded that as compared with carbaryl and Malathion (commercial insecticide), 
Table 4. Toxicity test of Artemisia absinthium against $T$. Castaneum at different concentrations/hour.

\begin{tabular}{|c|c|c|c|c|c|}
\hline Conc. \% & $1^{\text {st }}$ day & $2^{\text {nd }}$ day & $3^{\text {rd day }}$ & $4^{\text {th }}$ day & $5^{\text {th }}$ day \\
\hline \multirow[t]{2}{*}{$5 \%$} & $7.0 \mathrm{a}$ & $7.0 \mathrm{a}$ & $9.0 \mathrm{a}$ & $8.0 \mathrm{a}$ & $6.0 \mathrm{a}$ \\
\hline & $70 \%$ & $70 \%$ & $90 \%$ & $80 \%$ & $60 \%$ \\
\hline \multirow[t]{2}{*}{$2.50 \%$} & $5.0 \mathrm{ab}$ & $6.0 \mathrm{a}$ & $7.0 \mathrm{ab}$ & $7.0 \mathrm{a}$ & $6.0 \mathrm{a}$ \\
\hline & $50 \%$ & $60 \%$ & $70 \%$ & $70 \%$ & $60 \%$ \\
\hline \multirow[t]{2}{*}{$1.25 \%$} & $2.0 \mathrm{bc}$ & $5.0 \mathrm{a}$ & $5.0 \mathrm{bc}$ & $3.0 \mathrm{~b}$ & $4.0 \mathrm{a}$ \\
\hline & $20 \%$ & $50 \%$ & $50 \%$ & $30 \%$ & $40 \%$ \\
\hline \multirow[t]{2}{*}{$0.63 \%$} & $2.0 \mathrm{bc}$ & $4.0 \mathrm{a}$ & $3.0 \mathrm{c}$ & $3.0 \mathrm{~b}$ & $3.0 \mathrm{a}$ \\
\hline & $20 \%$ & $40 \%$ & $30 \%$ & $30 \%$ & $30 \%$ \\
\hline \multirow[t]{2}{*}{$0.31 \%$} & $1.0 \mathrm{c}$ & $4.0 \mathrm{a}$ & $3.0 \mathrm{c}$ & $2.0 \mathrm{~b}$ & $3.0 \mathrm{a}$ \\
\hline & $10 \%$ & $40 \%$ & $30 \%$ & $20 \%$ & $30 \%$ \\
\hline STD. Err. & 1.461 & 1.633 & 1.633 & 1.633 & 1.633 \\
\hline $\begin{array}{l}\text { LSD } \\
\mathrm{LC}_{50}\end{array}$ & $\begin{array}{c}3.254 \\
3.85\end{array}$ & $\begin{array}{c}3.639 \\
4.91\end{array}$ & $\begin{array}{c}3.639 \\
3.51\end{array}$ & $\begin{array}{c}3.639 \\
3.27\end{array}$ & $\begin{array}{c}3.639 \\
3.59\end{array}$ \\
\hline
\end{tabular}

Means in each row followed by the same letter are not significantly different at LSD test $(\mathrm{P}=0.05)$, while numbers in parenthesis indicate inhibition percentage over control

marigold leaf powder and neem seed extracts possess ability and are used as an alternative natural insecticide toward T. castaneum in stored products. Five different concentrations of Mentha royleana were selected for the estimation of toxicity level and mortality against T. castaneum.

The results revealed that concentration and mortality were directly proportional. At the highest concentration of $5 \%$ extract of Mentha royleana, mortality of $100 \%$ was observed. At $2.50 \%, 1.25 \%, 0.63 \%$, and $0.31 \%$ concentration the mortalities observed were $90 \%$, $70 \%, 50 \%$, and $30 \%$, respectively. The same type of plant was used by other scientists, but the species was different. They used it as repellent as well as toxicant against $T$. castaneum. The results were almost the same but the little difference might be due to climatic conditional changes, topography of area, and species difference. Manzoori et al. [21] found that the wild plant species contained the properties of pest control. The 5 ethanolic extracts of plant leaves - Cymbopogon citratus (Lemongrass), Melia azedarach (Bakain), Myrtus communis (Habulas), Mentha longifolia (mint), and Datura stramonium (Datura) - were used against pests viz., red flour beetle (T. castaneum. Herbst), gram dhora (Callosobruchus chinensis. L), and sawtoothed grain beetle (Oryzaephilus surinamensis. L). The results showed that the extracts had lethal as well as repellent actions against the test insects. Nadeem et al. [22] conducted studies on Azadirachta indica A. Juss (Neem) seed extracts and Citrullus colocynthis L. (Tumha) fruit ethanol extract to assess the effects of doses of $10 \%, 7.5 \%, 5 \%$, and $2.5 \%$ against T. Castaneum. The result showed that the seed extract of neem against T. Castaneum were dose-dependent, and at concentrations of $2.5 \%$ the mortality record was $35.93 \%$, at concentration of $5 \%, 7.5 \%$, and at $10 \%$

\section{a) Mean toxic effect of insecticides}

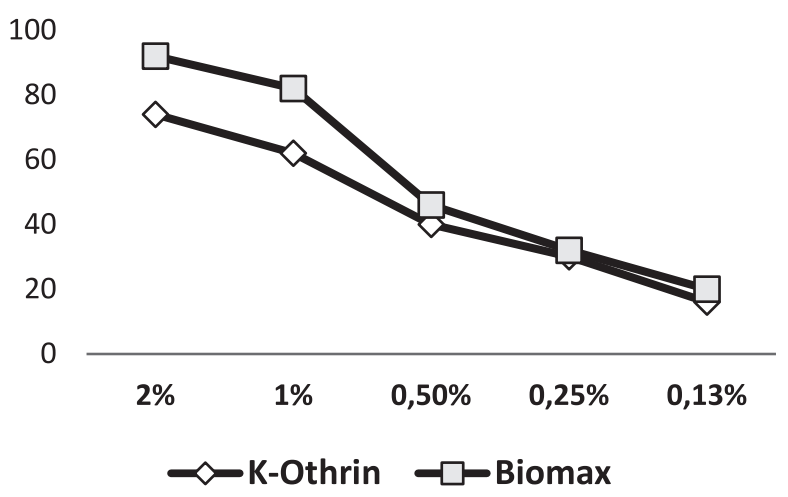

b) Mean toxic effect of botanical extract

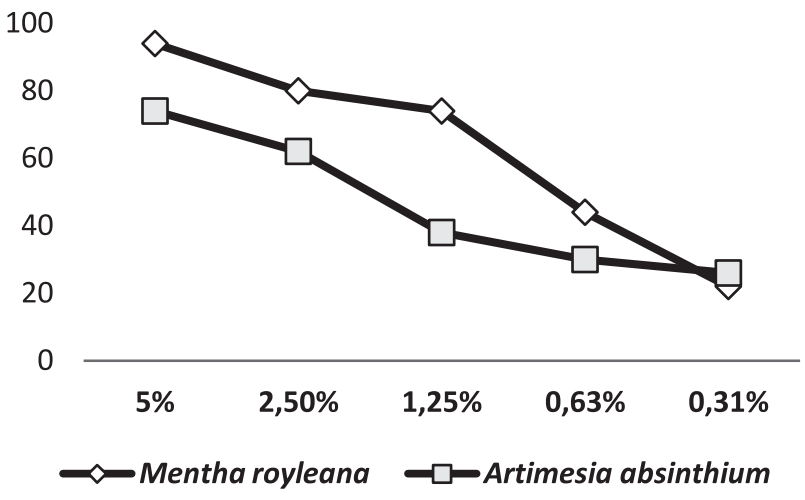

Fig. 1. Mean toxic effect of insecticides and botanical extracts against T. Castaneum. 
the mortality recorded was $47.77 \%, 55.92 \%$, and $64.44 \%$, respectively.

In contrast, during the current studies the botanical extract of Artemisia absinthium in various concentrations was used as insecticide against $T$. castaneum, which showed a very low to medium toxicity against the said stored grain pest. Sagheer et al. [23] examined the toxicological and repellent effects four plant acetone extracts at different concentrations viz 10\% Khar booti (Salsola baryosma), 7.5\% kust-e-shireen (saussurea costus), 5\% hermal (Pegnum harmala) and $2.5 \%$ tobacco (Nicotiana tabacum) against T. castaneum Herbst. The above research showed the effects of different wild, medicinal, and cultivated plants against the tested storage grain pest. This means there are some compounds present in the plants that are useful to human beings but effective against other organisms. The results of the present study are related to the current work due to the relationship with the concentration, but in the present study wild plant species were used as repellents - not as medicinal plants.

Likewise, in current research different concentrations of Artemisia absinthium were used to assess the toxicity and mortality against the flour beetle (T. castaneum). The selected concentrations for the treatment were $5 \%, 2.5 \%, 1.25 \%, 0.625 \%$, and $0.3125 \%$. The highest mortality was shown by the extract with higher concentrations, and while concentration decreased mortality decreased, and vice versa. At 5\% concentration the highest mortality detected was $90 \%$. This plant has many medicinal values but was used against the storage pest as a botanical insecticide for the first time in the study area. As Table 4 shows, these plants contain the toxin for flour beetle. The results might be due to the strong smell or its bitter taste, or may be due to other compounds present in it. This plant has many medicinal values in this area.

Dastagir and Hussain [24] reported on the insecticidal activity of plant exacts. Popovic et al. [25] studied the mortality rate and insecticidal activity of 9 important plant oils with known concentrations against T. castaneum (Herbst). Hameed et al. [26] studied 2 plant extracts, namely Azadirchta indica (Neem) and Nerium oleander (Kanair), fermented products Actinomycetales bacterium and Saccharopolyspora spinosa, and commercial Spinosad biological insecticide were used to evaluate the insecticidal and persistence against T. castaneum Herbst. Kalita and Bhola [27] studied Dichloromethane extract of Jatropha curcus L, Datura metel, Lantana camara, and Calotropis procera A. for mortality and repellent effects on T. castaneum Herbst. The results were relatively the same in that all the botanical plants somehow contain toxin for storage pests but have very less mammalian toxicity. Plants in the present study used against other storage pest might be effective. These plants may have repellent effects like other bio pesticides. More than $80 \%$ mortality shown by tested plants revealed that they contain toxic compounds as well as repellent components.

\section{Acknowledgements}

This study is a part of the M.Phil. degree program and was possible due to the technical support and guidance of officials from the Agriculture Department at Gilgit-Baltistan.

\section{References}

1. GANDHI N., PILLAI S., PRABHUDAS P. Efficacy of Pulverized Punica granatum (Lythraceae) and Murraya koenigii (Rutaceae) Leaves against Stored Grain Pest Tribolium castaneum (Coleoptera: Tenebrionidae). International Journal of Agriculture \& Biology, 12 (4), 2010.

2. JAYAKUMAR M., ARIVOLI S., RAVEEN R., TENNYSON S. Repellent activity and fumigant toxicity of a few plant oils against the adult rice weevil Sitophilus oryzae Linnaeus 1763 (Coleoptera: Curculionidae). Journal of Entomology and Zoology Studies. 5 (2), 324, 2017.

3. WAGAN TA., HU D., HE Y., NAWAZ M., NAZIR T., MABUBU J I., HUA H. Repellency of three plant essential oils against red flour beetle Tribolium castaneum (Herbst, 1797) (Coleoptera: Tenebrionidae) Un biti, Tribolium castaneum (Herbst, 1797) (Coleoptera: Tenebrionidae). Türk. entomol. derg. 40 (3), 2016.

4. HANIF CH.M.S., HASAN M-UL., SAGHEER M., SALEEM S., ALI K., AKHTAR S. Comparative insecticidal effectiveness of essential oils of three locally grown plants and phosphine Gas against Trogoderma granarium. Pak.J.Agri.Sci. 52 (3), 709, 2015.

5. AKHTAR S., HASAN M-UL-., SAGHEER M., JAVED N. Antifeedant Effect of Essential Oils of Five Indigenous Medicinal Plants Against Stored Grain Insect Pests. Pak. J. Zool. 47 (4), 1045, 2015.

6. IRAM N., ARSHAD M., AKHTER N. Evaluation of Botanical and Synthetic Insecticide for the Control of Tribolium castaneum (Herbst) (Coleoptera: Tenebrionidae). BioAssay: 8, 3, 2013.

7. KHAN S., TANING C.N.T., BONNEURE E., MANGELINCKX S., SMAGGHE G., SHAH M.M. Insecticidal activity of plant-derived extracts against different economically important pest insects. Phytoparasitica DOI 10.1007/s12600-017-0569-y, 2017.

8. ASRAR M., ASHRAF N., HUSSAIN S.M., ZIA K., RASOOL B. Toxicity and repellence of plant oils against Tribolium castaneum (Herbst), Rhyzopertha dominica (F.) and Trogoderma granarium (E.). Pak. Entomol., 38 (1), 55, 2016.

9. KHAN I., QURESHI N., KHAN1SA., ALI A., AHMAD M., JUNAID K. Efficacy of Several Plant Extracts as Growth Inhibitors against Red Flour Beetle, Tribolium castaneum (Herbst) (Coleoptera: Tenebrionidae). Acta zool. bulg., 68 (3), 443, 2016.

10. SAEED Q., IQBAL N., AHMED F., REHMAN S., ALVI A M. Screening of Different Plant Extracts Against Tribolium Castaneum (Herbst.) Under Laboratory Conditions. Sci.Int. (Lahore), 28 (2), 1219, 2016.

11. PADÍN S.B., FUSÉ C., URRUTIA MI., DAL B.G.M. Toxicity and repellency of nine medicinal plants against Tribolium castaneum in stored wheat. Bulletin of Insectology 66 (1), 45, 2013. 
12. AKHTAR K., AZMI M.A., NAQVI S.N.H., TARIQ R.M. Effect of Acorus Calamus Extract and Rb-B (Neem Product) Against. Pakistan j. Entomol. Karachi, 22 (1-2), 5, 2007.

13. YALLAPPA RAJASHEKAR*, THIMMAPPA SHIVANANDAPPA. Grain Protection Potential of Decaleside II, a New Plant-Derived Natural Insecticide. Advances in Entomol. 2, 144, 2014.

14. JABILOU R., ENNABILI A., SAYAH F. Insecticidal activity of four medicinal plant extracts against Tribolium castaneum (Herbst) (Coleoptera: Tenebrionidae). Afr. J. Biotechnol., 5 (10), 936, 2006.

15. KAMALI HHEL . Effect of certain medicinal plant extract against stored grain pest T. castaneum Herbst. Am. Eurasian J. Sustain. Agric., 3 (2), 139, 2009.

16. ALI WK., MOHAMMED HH. Toxic Effect of Some Plant Extracts on the Mortality of Flour Beetle Tribolium confusum (Duval) (Coleoptera: Tenebrionidae). Entomol Ornithol Herpetol 2: 115. doi:10.4172/2161-0983.1000115, 2013.

17. VALSARAJ R., PUSHPANGADAN P, SMITT U W., ADSERSEN A., NYMAN U. Antimicrobial screening of selected medicinal plants from India, Journal of Ethnopharmacology, 58, 75, 1997.

18. TOEWS M.D., CAMPBELL J.F., ARTHUR F.H. The presence of flour affects the efficacy of aerosolized insecticides used to treat the red flour beetle, Tribolium castaneum. J. Insect Sci. 10, 1, 2010.

19. ARTHUR, F.H. Aerosol distribution and efficacy in a commercial food warehouse. Insect Sci. 15, 133, 2008

20. ISLAM. M. S., TALUKDER F. A. Toxic and residual effects of Azadirachta indica, Tagetes erecta and Cynodon dactylon seed extracts and leaf powders towards Tribolium castaneum. Zeitschrift für Pflanzenkrankheiten und Pflanzenschutz Journal of Plant Diseases and Protection 112 (6), 594, 2005.
21. MANZOOR F., GHAZALA N., SADIA S., SAADIYA., ASMA M. Effect of ethanolic plant extracts on three storage Grain pests of economic importance. Pak. J. Bot., 43 (6), 2941, 2011

22. NADEEM M., JAMSHAID I., MASOOD K., KHATTAK M., AHMAD S. (2012). Management of Tribolium castaneum (Hbst.) (Coleoptera: Tenebrionidae) Using Neem (Azadirachta indica A. Juss) and Tumha (Citrullus colocynthis (L.). Pakistan J. Zool. 44 (5), 1325, 2012.

23. SAGHEER M., KAZAM A., MANSOOR-UL-HASAN, ABDUL R., UMAIR S., ABID A. Repellent and Toxicological Impact of Acetone Extracts of Nicotiana tabacum, Pegnum hermala, Saussurea costus and Salsola baryosma against Red Flour Beetle, Tribolium castaneum (Herbst). Pakistan J. Zool. 45 (6), 1735, 2013.

24. DASTAGIR G., HUSSAIN F. Phytotoxic and insecticidal activity of plants of Family zygophyllaceae and euphorbiaceae. Sarhad J. Agric. 29 (1), 83, 2013.

25. POPOVIĆ A., JOVANA Š., DEJAN O., PERO Š. Effects of essential oil formulations on the adult insect tribolium castaneum (Herbst) (col., tenebrionidae). Journal of central European agriculture, 14 (2), 181, 2013.

26. HAMEED A., SHOAIB F., ALTAF H., MUHAMMAD I., MUSSURAT H., MUHAMMAD N., ASIF S., HAM MAD H., MUHAMMAD A.S., ABDUL LT. Toxicological effects of neem (Azadirachta indica), Kanair (Nerium oleander) and spinosad (Tracer $240 \mathrm{SC}$ ) on the red flour beetle () (Herbst.). African Journal of Agricultural Research 7 (4), 555, 2012.

27. KALITA S., BHOLA R.K. Repellency and Toxicity of Some Plant Extracts Against Tribolium Castaneum (Herbst). Global Journal for Research Analysis, 3 (6), 216, 2014. 
